\title{
BIOMASS SUPPLY CHAIN ANALYSIS WITH DENSIFIED WASTE ${ }^{1}$
}

Elisangela Fernandes da Silva Campana Possidônio ${ }^{2 *}$, João Eduardo Azevedo Ramos da Silva ${ }^{3}$ and Eli Angela Vitor Toso ${ }^{3}$

\footnotetext{
${ }^{1}$ Received on 07.04.2015 accepted for publication on 03.12.2015.

${ }^{2}$ Universidade Federal de São Carlos, Programa de Pós-Graduação em Engenharia de Produção, Campus Sorocaba, Sorocaba, SP - Brasil. E-mail: <licampana@ufscar.br>

${ }^{3}$ 3Universidade Federal de São Carlos, Departamento de Engenharia de Produção de Sorocaba, Campus Sorocaba, Sorocaba, SP - Brasil. E-mail: <jesilva@ufscar.br> and <eli@ufscar.br>.

${ }^{*}$ Corresponding author.
}

\begin{abstract}
The possibility to vary the energy matrix, thus reducing the dependency on fossil fuels, has amplified the acceptance of biomass as an alternative fuel. Despite being a cheap and renewable option and the fact that Brazil is a major producer of waste from agriculture and forestry activities, the use of these materials has barriers due to its low density and low energetic efficiency, which can raise the costs of its utilization. Biomass densification has drawn attention due to its advantage in comparison to in natura biomass due to its better physical and combustion characteristics. The objective of this paper is to evaluate the impact of biomass densification in distribution and transport costs. To reach this objective, a mathematical model was used to represent decisions at a supply chain that coordinates the purchase and sale of forestry and wood waste. The model can evaluate the options to deliver biomass through the supply chain combining demand meeting and low cost. Results point to the possibility of an economy of $60 \%$ in transport cost and a reduction of $63 \%$ in the required quantity of trucks when densified waste is used. However, costs related to the densifying process lead to an increase of total supply costs of at least $37,8 \%$ in comparison to in natura waste. Summing up, the viability of biomass briquettes industry requires a cheaper densification process.
\end{abstract}

Keywords: Biomass Waste; Transport; Mathematical modeling.

\section{ANALLISE DA REDE DE ABASTECIMENTO DE BIOMASSA COM RESÍDUOS DENSIFICADOS}

\begin{abstract}
RESUMO - A possibilidade de diversificação da matriz energética, com redução da dependência dos combustiveis fósseis, tem ampliado a aceitação da biomassa como opção de energia alternativa. Apesar de ser uma fonte barata e renovável e o Brasil ser um grande produtor de resíduos de origem agrícola eflorestal, o aproveitamento desses materiais encontra barreiras devido à baixa densidade e ao baixo rendimento energético, que podem elevar o custo para sua utilização. A densificação da biomassa tem chamado a atenção devido à superioridade sobre a biomassa in natura em relação às características físicas e de combustão. O objetivo deste trabalho é avaliar o impacto da densificação da biomassa na distribuição e nos custos de transporte. Para alcançar esse objetivo foi utilizado um modelo matemático para representar as decisões em uma rede que intermedia a compra e a venda de resíduos madeireiros, tomada como estudo de caso. Os resultados indicam a possibilidade de economia de até $60 \%$ nos custos de transporte e redução de até $63 \%$ na quantidade de veículos ao se trabalhar com os resíduos densificados. No entanto, os custos com o material densificado elevaram os custos totais de abastecimento no mínimo em $37,8 \%$ em relação aos resíduos in natura.

Palavras-chave: Modelagem matemática; Transporte; Briquete.
\end{abstract}




\section{INTRODUCTION}

The fact that fossil fuels are non-renewable, with major participation on the energetic matrix, and high power to contaminate the atmosphere represents an incentive to investigate alternative materials for energy generation (MARIN et al., 2011). According to Simioni and Hoelflich (2010) the use of these alternative materials is a powerful worldwide tendency, due its high efficiency and clean technology. Monteiro et al. (2012) also confirm worldwide interest in sustainable energy production and highlight the contribution that is expected from biomass energy.

According to Destouni and Frank (2010) perspectives for biomass use foresees forest and agricultural residues, together with organic waste. Moreira (2011) points out that biomass contributes twice as much to the reduction of greenhouse gases (GHG): at the time of its growth, due to the absorption and storage of carbon through photosynthesis; and by reducing carbon emissions, when replacing fossil fuels.

In Brazil, ANEEL (2008) emphasizes that biomass is one of the main options for the Brazilian energy matrix diversification, with the benefit of reducing dependence on fossil fuels. Due to suitable geographical conditions, Brazil can take a leading position in the production and use of biomass as an energy resource (BRASIL, 2007). Protásio et al. (2011) support this statement, as Brazil has great availability of biomass residues from agriculture and forestry. However, the use of biomass residues depends on a careful evaluation of the available quantity of material, its quality, a marketing analysis of competing uses and an evaluation of available technologies for energy transformation, among other technical, economic, social, and environmental issues (FURTADO et al., 2012;. KIM et al., 2011).

Despite being a cheap and renewable source, there are barriers that hinder a greater use of agriculture and forestry residues. Its low density and energy efficiency result in a high cost for its use, which is commonly used as arguments against it. (MONTEIRO et al., 2012).

In contrast, the biomass densification process enhances its physical and combustion characteristics in comparison to in natura biomass. This process reduces the moisture content, increases the energy content and combustion efficiency, and produces a more homogeneous material (OBERNBERGER; THEK,
2004). After densification, the material density is 4 to 10 times greater than in natura biomass (KARWANDY 2007).

Among the processing options to densify biomass, briquetting is a well-known alternative. In terms of energy, a ton of briquettes is equivalent to $7 \mathrm{~m}^{3}$ common wood (DE ANGELIS, 2007) with other advantages besides the increase of density, such as better transport and storage, increased energy efficiency, better handling of residues (MIGLIORINI, 1980; RODRIGUES etal., 2002; JUNGINGER et al., 2011), and lower transport costs (REIS et al., 2002; GRANADA et al., 2002).

Considering the benefits for energy generation that can be obtained with the use of biomass wastes, as well as the possible advantages of biomass densification process, this study analyzes the impact of residues densification in distribution operations and respective transport costs in a biomass supply chain.

\section{MATERIALS AND METHODS}

The method used in this paper is an extension of the classical transport model, by means of a case study. The mathematical model considers a supply chain that coordinates the transactions of forestry and wood industry residues between residues suppliers and industrial customers. Applied to this supply chain, two scenarios were evaluated: Scenario 1, which considered in natura waste and Scenario 2, with densified waste. In both scenarios two cases were considered: Case A - case study of the existing supply chain, respecting the relationship among suppliers and customers; and Case B - a study of the existing supply chain, without the rules of delivery of the existing supply chain, allowing for a more comprehensive analysis of the network configuration. All computational studies were designed using GAMS / CPLEX.

\subsection{Biomass transportation problem modeling}

The central problem is to determine the amount of material that must be transported between a set of origins and destinations to meet the demand. In order to minimize the total system cost, the model must indicate the type of vehicles and how many units to be used.

Physical characteristics of the waste - density and calorific value - were considered in the model. Density affects transport operations directly and the calorific value determines the biomass demand to each client. 
Potential biomass residues sources are spread geographically, with different production capacities. Each supplier generates only one type of material, which differs in density, calorific value, and acquisition price, as shown in Table 1. These suppliers deliver biomass waste to different customers, each of them with a specific biomass demand, according to the calorific value needed.

Waste transport is done by a heterogeneous fleet of vehicles owned by the supplier or hired as needed, with capacities ranging from 65 to $120 \mathrm{~m}^{3}$. The types of trucks considered were: moving floor trailers, dump trucks, side opening trailer truck, B-train and roll-on B-train.

The vehicles operate in cyclic trips, starting at the biomass supplier, where biomass is loaded and sent to the customer, where the material is unloaded, after which the vehicle returns to the supplier, starting a new cycle. Average values for the loading and unloading times were considered. Loading ranges from 40 to 120 minutes and unloading from 15 to 45 minutes. The cycle time is composed of the sum of loading, transport from supplier to customer, unloading, and return to the supplier. The speed considered in the model were 40 and $60 \mathrm{~km}$ $/ \mathrm{h}$, respectively, for the speed of loaded vehicle and empty vehicle. The cycle time of the vehicle is a parameter calculated previously to model run and varies according to each origin-destination route.

Transportation costs comprise fixed and variable costs, and were calculated for every supplier-customer route and for each type of vehicle. Fixed costs include depreciation, return on invested capital, labor, administrative costs, vehicle insurance and property, while variable costs include fuel, lubricating, tires, cleaning, and maintenance.

The vehicles are loaded up to one of the restrictions: volume or weight, which varies according to the density of each residue and the legal weight limit of each type of vehicle. The load per trip is a previously calculated parameter. The load per trip was considered to be made up of only one type of waste and the vehicles can perform multiple trips within a time limit, established as a month period, limited by vehicles availability.

Indexes, parameters, variables, constraints, and objectives considered in the transportation model are presented below.

\section{Indexes:}

f supplier $\{1, \ldots, F\}$

c customer $\{1, \ldots, C\}$

$\mathrm{t}$ vehicles, owned and rented $\{1, \ldots, \mathrm{T}\}$

$t_{p}=$ owned vehicles e $t_{c}=$ rented vehicles, $t=$ $t_{p}+t_{c}$

Where $\mathrm{F}$ corresponds to the total number of suppliers, $\mathrm{C}$ to the total number of customers and $\mathrm{T}$ to the total amount of vehicles.

\section{Parameters:}

Custo $_{f}$ unitary cost of a ton of waste from each supplier $\mathrm{f}$,

$d_{c}$ demand, in calorific value, of customer c,

$k_{f}$ waste supply capacity of $\operatorname{supplier} f$,

$p c_{f}$ waste calorific value of supplier $f$,

$q_{t f}$ quantity of waste transported by vehicle $\mathrm{t}$ from supplier $f$

$d h_{t}$ available hours per month of each vehicle $t$,

frete $_{t f c}$ transportation cost from supplier f to customer c using vehicle $t$,

tct $t_{f c}$ cycle time from supplier f to customer $c$,

$r a_{f c}$ binary parameter to indicate the availability of supplier $f$ to deliver biomass to customer $c$, being 1 if available or 0 if not available;

Table 1 - Characteristics of the materials.

Tabela1 - Características dos materiais.

\begin{tabular}{|c|c|c|c|c|}
\hline \multirow[t]{3}{*}{ Parameters } & \multicolumn{4}{|c|}{ Type of Material } \\
\hline & \multicolumn{2}{|c|}{ Scenario 1} & \multicolumn{2}{|c|}{ Scenario 2} \\
\hline & Sawdust & Forestry & Recycled wood & Briquette \\
\hline Acquisition $\operatorname{cost}(\mathrm{R} \$ / \mathrm{t})$ & 80.00 & 90.00 & 100.00 & 350.00 \\
\hline $\operatorname{Density}\left(\mathrm{kg} / \mathrm{m}^{3}\right)$ & 400 & 300 & 250 & 1,000 \\
\hline Calorific Value(kcal/kg) & 2,200 & 2,800 & 3,200 & 4,800 \\
\hline
\end{tabular}

Source: Studied Company.

Fonte: Empresa do Estudo de Caso. 
$n_{t f}$ amount of vehicles $t$ available at supplier $f$;

$\alpha_{t}$ penalization for the quantity of vehicles $t$ used.

\section{Decision Variables:}

$x_{t f c}$ quantity of trips that vehicle $t$ transports residues from supplier $f$ to client $c$,

$y_{t f}$ total vehicles of type t used by supplier $f$.

\section{Model formulation:}

Minimize:

$$
\sum_{f \in F} \sum_{c \in C} \sum_{i \in T}\left(\left(x_{i j c} q_{i j} \text { custo }_{f}\right)+\left(x_{i f c} \text { frete }_{t / c}\right)\right)+\sum_{t \in t c} \sum_{f \in F} \alpha_{i} y_{i f}
$$

Subject to:

$\sum_{f \in F} \sum_{i \in T} x_{i f c} q_{t f} p c_{f} r a_{f c} \geq d_{c}, c \in C$

$\sum_{c \in C} \sum_{t \in T} x_{t f c} q_{t f} \leq k_{f}, f \in F$

$\sum_{c \in C} x_{l f c} t c t_{f_{c}} \leq d h_{t} y_{t f}, f \in F, t \in T$

$y_{t f} \leq n_{t f}, t \in T_{p}, f \in F$

$x_{t f c}, y_{t j} \in Z_{N T}^{\prime}$

The objective function (1) aims to minimize the total cost of acquisition and transportation of waste, which depends on each supplier. In addition, it considers a penalization for the use of rented vehicles, which affects the quantification of vehicle fleet used by suppliers. With the penalization applied to rented vehicles, the model can prioritize the use of owned fleet of vehicles. Constraint (2) determines that the demand of calorific value of each client will be supplied by materials sent by all sources. Constraint (3) stipulates that the amount of residue that can be transported must not exceed the availability of the suppliers. Equation (4) ensures that if a vehicle is used by a supplier, the total amount of trips must not exceed the limit of hours per month of this vehicle at this supplier. Constraint (5) ensures that the number of vehicles used by suppliers is not greater than the available fleet. Finally, restriction (6) indicates the integrality of variables.

Constraint (4) was based on Albareda-Sambola et al. (2009) mathematical model, where the variable used is binary and the vehicle fleet is considered homogeneous. In this paper an integer variable is used due to the adoption of a heterogeneous fleet. Therefore, it is possible to quantify the suppliers' fleet. This is applicable considering that the vehicle fleet can be outsourced according to the needs of each supplier.

\section{RESULTS}

\subsection{In natura Residues Scenario - 1}

The first computational study was applied to the existing supply chain, respecting the real relationship between customers and suppliers (Situation A). This situation is quite restricted; however, the results are relevant for comparison with other scenarios.

All parameters were kept in Situation B, except for the rules of delivery, so all suppliers could deliver biomass to all customers, promoting a greater flexibility in the supply chain.

In both studies, customer demands were met and supplier's capacities were respected. The total supply cost was $R \$ 4,223,226$ in situation $A$ and $R \$ 3,681,141$ in situation B. These figures show that flexibility in delivery allowed for a reduction of $12.8 \%$ in the total supply cost.

Detailing the total supply cost, residues cost in situation $\mathrm{A}$ is responsible for a percentage of $57.5 \%$ while the transportation cost is $42.5 \%$. On the other hand, in situation $\mathrm{B}$, residues cost is responsible for $62.6 \%$ of the total supply cost and transport represents a percentage of $37.4 \%$, as seen in Table 2 .

Comparing the two situations, a flexible biomass supply chain, enabling the model to choose a better delivery alternative, provides a reduction in the biomass costs of $5.1 \%$ and a $23.3 \%$ reduction in transportation costs.

The reduction in biomass cost is due to new supply options, enabled at situation B. The mathematical model minimizes the total supply cost, balancing costs and calorific value, so that more expensive residues in terms of rate cost/ton, are preferable than others with lower calorific value.

Preferences for high calorific value residues causes a reduction of the amount of waste for the supply chain, ensuring a reduction in biomass cost and transportation costs, once less trips and fewer vehicles are necessary. 
Table 2 - Results of situations A and B of Scenario 1 (In natura waste).

Tabela 2 - Resultados das situações A e B do Cenário 1 (Resíduos in natura).

\begin{tabular}{lcc}
\hline Parameters & \multicolumn{1}{c}{ Scenario 1 (in natura) } \\
\cline { 2 - 3 } & Situation A & Situation B \\
\hline Total cost (R\$) & $4,223,226$ & $3,681,141$ \\
Total transportation cost (R\$) & $1,793,181$ & $1,375,381$ \\
Material cost $(\mathrm{R} \$)$ & $2,430,045$ & $2,305,760$ \\
Distance covered $(\mathrm{km})$ & 416,750 & 331,486 \\
Average energy cost $(\mathrm{R} \$ \mathrm{kcal})$ & 0.035 & 0.033 \\
Total cycle time $(\mathrm{h})$ & $10,609.44$ & $8,795.59$ \\
Average cost per kilometer $(\mathrm{R} \$ /$ covered $\mathrm{km})$ & 4.30 & 4.15 \\
Percentage of transport cost in total costs $(\%)$ & 42.5 & 37.4 \\
Total vehicles used & 49 & 40 \\
Total hired vehicles & 22 & 5 \\
Quantity of Trips & 1,047 & 1,027 \\
Amount of residues used from supplier 1 (t) & 20,000 & 7,181 \\
Amount of residues used from supplier 2 $(\mathrm{t})$ & $7,000.5$ & 14,792 \\
Amount of residues used from supplier 3 $(\mathrm{t})$ & 2,000 & 4,000 \\
\hline
\end{tabular}

In situation A, 49 vehicles are required to cover 1,047 trips between suppliers and customers, while in situation B only 40 vehicles are necessary to cover 1,027 trips.

To complete the required trips, owned fleet was prioritized and rented vehicles were used only when strictly necessary, as there is penalty for rented vehicles, which forced the use of owned fleet. Table 2 shows that in situation A there is a need for 22 rented vehicles, while in situation B only 5 vehicles rented vehicles are necessary.

In situation $\mathrm{B}$, less vehicles were hired as a consequence of the flexible supply chain as new choices of suppliers were chosen allowing for a better allocation of owned vehicles.

Summing up, besides having a better allocation of the owned vehicles, the flexibility of situation B provides a $23,3 \%$ reduction in total transport costs; less $18.4 \%$ in the amount of vehicles; less $20.5 \%$ total distance covered and a $17.1 \%$ reduction in total cycle time.

\subsection{Densified Residues Scenario - 2}

As done in Scenario 1, Scenario 2 considers the same two situations: Situation A, which considers the original biomass supply chain, respecting the sources of residues and their customers and Situation B, which allows for the delivery of biomass to customers from any supplier. However, the product considered was the densified waste in briquettes form.
These scenarios were also tested by means of a mathematical model to compare the densification of residues. All parameters from the previous scenarios were kept, only the parameters referred to briquettes characteristics were altered.

In the two situations, $\mathrm{A}$ and $\mathrm{B}$, demands from customers were met and the capacity of suppliers was respected. The total supply cost of the network was $\mathrm{R} \$ 5,981,282$ in situation A and R \$ 5,819,985 in situation $\mathrm{B}$, a reduction of $2.7 \%$.

In this scenario, we considered that all suppliers have densified residues, with the same physical characteristics. In this analysis, the cost difference between situations A and B is due to the more flexible supply chain to meet the customers' demands, which implies in less distances covered.

Considering total costs of the supply chain, biomass cost in situation A represents a percentage of $85.4 \%$ while transport costs is $14.6 \%$. In situation $\mathrm{B}$, biomass cost is $87.7 \%$ and transport costs is $12.3 \%$, as shown in Table 3.

Comparing the costs of situation A and situation $\mathrm{B}$, it is possible to verify that a more flexible supply chain can reduce the transport cost in $18.39 \%$.

In situation $\mathrm{A}$, the mathematical model considers the use of the following types of vehicles: dump trucks, side opening trailer trucks and B-train, respectively with the quantities of 2,7 , and 14 units, totalizing 23

Revista Árvore, Viçosa-MG, v.40, n.2, p.355-362, 2016 
Table 3 - Results of situations A and B of scenario 2 (densified waste).

Tabela 3 - Resultados das situações $A$ e $B$ do cenário 2 (resíduos densificados).

\begin{tabular}{|c|c|c|}
\hline \multirow[t]{2}{*}{ Parameters } & \multicolumn{2}{|c|}{ Scenario 2 (densified) } \\
\hline & Situation A & Situation B \\
\hline Total cost $(\mathrm{R} \$)$ & $5,981,282$ & $5,819,985$ \\
\hline Total transportation cost $(\mathrm{R} \$)$ & 873,382 & 712,785 \\
\hline Material cost $(\mathrm{R} \$)$ & $5,107,900$ & $5,107,200$ \\
\hline Distance covered $(\mathrm{km})$ & 195,138 & 148,662 \\
\hline Average energy cost $(\mathrm{R} \$ / \mathrm{kcal})$ & 0.073 & 0.073 \\
\hline Total cycle time $(\mathrm{h})$ & $4,969.08$ & $3,956.41$ \\
\hline Average cost per kilometer ( $\mathrm{R} \$ /$ covered $\mathrm{km})$ & 4.47 & 4.79 \\
\hline Percentage of transport cost in total costs $(\%)$ & 14.6 & 12.3 \\
\hline Total vehicles used & 23 & 18 \\
\hline Quantity of Trips & 491 & 467 \\
\hline Amount of residues used from supplier $1(t)$ & 9,175 & 2,304 \\
\hline Amount of residues used from supplier $2(t)$ & 4,084 & 9,472 \\
\hline Amount of residues used from supplier $3(\mathrm{t})$ & 1,335 & 2,816 \\
\hline
\end{tabular}

vehicles. In situation $B$, the same types were used with the quantities of 1,1 , and 16 units, respectively, totalizing 18 vehicles.

In situation $\mathrm{B}$ a reduction in transport cost of $23.8 \%$ was observed when compared to situation $\mathrm{A}$, as a reduction of the total distance covered.

\section{DISCUSSION}

Considering supply chain total costs, it is possible to verify that only situation B of Scenario 1 , which uses in natura residues in a more flexible supply chain, can bring some advantage in comparison to the original system.

As stated by Reis et al. (2002) and Granada et al. (2002), densification indeed reduces transport costs. Considering the scenario with densified waste, a reduction from 51 to $60 \%$ is observed in transport costs in comparison to in natura waste. On the other hand, a $110 \%$ increase is observed in acquisition cost, which increases the supply chain total cost between $37.8 \%$ and $41.6 \%$.

Marvin et al. (2012) mention that biomass transport is one of the barriers to be overcome in order to meet the increase of biofuels production demand. As observed, densification reduces the total trips, the total distance covered, and the necessity of vehicles, while the supply chain demand is met. These advantages associated to the densification process bring more efficiency to biomass transport.
Reduction on the need of vehicles, trips, and distance covered can also bring other benefits to the companies that are members of the biomass supply chain, such as a reduction on manpower required and tolls cost.

In Situation B of Scenario 2, the total quantity of trips was reduced in $55 \%$ and the transport cost per kilometer was $\mathrm{R} \$ 4.79 / \mathrm{km}$. Although this is the greatest value from the four situations analyzed, it is the smallest percent value of the total supply chain cost, with $12.3 \%$.

Considering the biomass costs and the breakeven point of total supply costs with densified waste and in natura waste, it is possible to verify that densification process cannot exceed $\mathrm{R} \$ 919,799$ when the situation A of Scenarios 1 and 2 are compared. This value is found by subtracting the cost related to biomass acquisition and the transport cost of densified waste from the total supply chain cost of scenario 1; therefore, this value is the limit to the densification process cost. Considering that 14,592 tons of residues are necessary in order to deliver to the supply chain, it can be stated that the cost per ton of briquettes cannot exceed $\mathrm{R} \$ 229.57$ and the cost of energy cannot exceed R $\$ 0.048 / \mathrm{kcal}$

Using the same logic to compare situation A from Scenario 1 to situation B from Scenario 2, the cost of ton of briquette in this situation cannot exceed $\mathrm{R} \$ 240.57$ and the energetic cost cannot exceed $\mathrm{R} \$ 0.05 / \mathrm{kcal}$.

The main advantage of densification is related to residues transport. The possibility to reduce the quantity of vehicles can be of a minor importance to 
rented fleet but it is an important decision in case of owned fleet.

The flexibility of delivery, verified through situation B in both scenarios promotes a reduction of supply chain total costs, guarantees the use of a smaller fleet, and reduces the need to rent vehicles.

\section{CONCLUSION}

Waste densification influences the logistics operations in biomass supply chain as it brings benefits to transport operation such as the reduction of fleet and the reduction of the quantity of trips to deliver biomass to customers. However, in terms of total supply chain costs, densified waste does not bring advantages in comparison to in natura residues, due to the high cost of material. Considering that a specific supply chain was evaluated, different results may be found if new values are set to the adopted parameters.

From the customers' point of view, the economic analysis suggests that there is no advantage to work with densified waste. Despite the benefits of a higher density, ease of transport and storing, and higher energetic efficiency, the costs of densification are too high. On the other hand, from the suppliers' point of view, below a certain densification cost, as discussed previously, this process can be viable, as transport shows interesting benefits.

The methodology used in this paper is considered suitable to meet the objectives proposed, once the mathematical model enabled the comparison of the scenarios with in natura and densified waste. If needed, the model can be easily modified and used as a decision support tool to evaluate other biomass supply chain settings. It is possible to consider, for instance, new densified waste suppliers, as well as suppliers of nonrenewable fuels in the same mathematical model. So, the model can be easily modified to evaluate alternatives for the supply chain considering two major benefits: low-cost operation and delivery guarantee.

Results obtained from the model in Scenario 1 reveal that there is inefficiency on waste distribution in the existing supply chain, as longer routes are used in contrast to shorter ones. The best result was found for situation B. The model found the best delivery strategy with the best suppliers to meet the demand, besides the type of vehicles and the amount of biomass.
In Scenario 2, despite the higher density and calorific value in comparison to in natura biomass, briquettes influenced negatively the total supply chain costs due to the high cost of acquisition.

Additional studies can be performed to consider variations on the cost of waste densification and alternatives to cheapen the densification process. It is expected that in the future new densification technologies can be developed, with consequent price reduction, stimulated by an increase on the biomass production scale, which can alter the results found.

\section{REFERENCES}

AGÊNCIA NACIONAL DE ENERGIA ELÉTRICA. Atlas de energia elétrica do brasil/ Agência Nacional de Energia Elétrica. Brasília: 2008. Disponível em: <www.aneel.gov.br>. Acesso em: 15 jul. 2012.

ALBAREDA-SAMBOLA, M.; FERNÁNDEZ, E.; LAPORTE, G. The capacity and distance constrained plant location problem. Computers \& Operations Research, n.36, p.597-611, 2009.

BRASIL. Ministério de Minas e Energia. Matriz energética nacional 2030. 2007. Disponível em: <http://www.mme.gov.br/spe/galerias/ arquivos/Publicacoes/ matriz_energetica_nacional_2030/ MatrizEnergeticaNacional2030.pdf $>$ Acesso em: 22 abr. 2013

DESTOUNI, G.; FRANK, H. Renewable energy. Ambio, n.39, p.18-21, 2010.

DE ANGELIS, B.L.D.; SAMPAIO, A.C.F.; TUDINI, O.G.; ASSUNÇÃO, M.G.T.; DE ANGELIS NETO, G. Avaliação das árvores de vias públicas da zona central de Maringá, Estado do Paraná: estimativa de produção de resíduos e destinação final. Acta Scientiarum - Agronomy, v.29, n.1, p.133$140,2007$.

FURTADO, T.S.; FERREIRA, J.C.; GRAND, M.A.; MUÑIZ, G.I.B.; QUIRINO, W.F. Mapeamento da frequência de uso e características da biomassa florestal utilizada para geração de energia em Lages, SC. Ciência Florestal, v.22, n.4, p.795$802,2012$.

Revista Árvore, Viçosa-MG, v.40, n.2, p.355-362, 2016

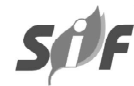


GRANADA, E.; LÓPEZ GONZÁLEZ, L.M.; MÍGUEZ, J.L.; MORAN, J. Fuel lignocellulosic briquettes, die design and products study. Renewable Energy, v.27, n.4, p.561-573, 2002.

JUNGINGER, M.; VAN DAM, J.; ZARRILLI, S.; MOHAMED, F.A.; MARCHAL, D.; FAAIJ, A. Opportunities and barriers for international bioenergy trade. Energy Policy, v.39, p.20282042, 2011.

KARWANDY, J. Pellet production from sawmill residue: a Saskatchewan perspective. [S.1.: s.n.], 2007.(Forintek Canada Corp Report, 29).

KIM, J.; REALFF, M.J.; LEE, J.H. Optimal design and global sensitivity analysis of biomass supply chain networks for biofuels under uncertainty. Computers \& Chemical Engineering, v.35, n.9, p.1738-1751, 2011.

MARÍN, E.A.C.; VELÁSQUEZ, H.J.C.; CÁRDENAS, E.L.M. Biocombustibles: búsqueda de alternativas. Revista CES Medicina Veterinaria y Zootecnia, v.6, n.2, p.118-123, 2011.

MARVIN, W.A.; SCHMIDT, L.D.; BENJAAFAR, S.; TIFFANY, D.G.; DAOUTIDIS, P. Economic optimization of a lignocellulosic biomass-toethanol supply chain. Chemical

Engineering Science, v.67, n.1, p.68-79, 2012.

MIGLIORINI, A.J. Densificação de biomassa florestal. Série Técnica IPEF, v.1, n.2, p.c-1c-9, 1980.

MONTEIRO, E.; MANTHA, V.; ROUBOA, A. Portuguese pellets market: analysis of the production and utilization constrains. Energy Policy, v.42, p.129-135, 2012.

MOREIRA, J.M.M.A.P. Potencial e participação das florestas na matriz energética. Pesquisa Florestal Brasileira, v.31, n.68, p.363-372, 2011.

OBERNBERGER, I.; THEK, G. Physical characteristics and chemical composition of densified biomass fuels with regard to their combustion behavior. Biomass and Bioenergy, v.27, p.653-669, 2004.

PROTÁSIO, T.P.; ALVES, I.C.N.; TRUGILHO, P.F.; SILVA, V.O.; BALIZA, A.E.R. Compactação de biomassa vegetal visando à produção de biocombustíveis sólidos. Pesquisa Florestal Brasileira, v.31, n.68, p.273-283, 2011.

REIS, B.O.; SILVA, I.T.; SILVA I.M.O.; ROCHA, B.R.P. Produção de briquetes energéticos a partir de caroços de açaí. 2002. Disponível em: $<$ http:// www.feagri.unicamp.br/energia/agre2002/pdf/ 0080.pdf $>$. Acesso em: 27 jul. 2012.

RODRIGUES, L.D.; SILVA, I.T.; ROCHA, B.R.P.; SILVA I.M.O. Uso de briquetes compostos para produção de energia do estado do Pará. In: ENCONTRO ENERGIA MEIO RURAL, 2002. Anais... [S.1.: s.n.], 2012. Disponível em:http:// www.proceedings.scielo.br/pdf/agrener/n4v2/ 129.pdf. Acesso em 21 jul. 2012.

SIMIONI, F.J.; HOEFLICH, V.A. Cadeia produtiva de energia de biomassa na região do planalto Sul de Santa Catarina: uma abordagem prospectiva. Revista Árvore, v.34, n.6, p.1091-1099, 2010. 